\title{
TINGKAT PEMAHAMAN SISWA PADA MATERI SISTEM PERSAMAAN LINEAR TIGA VARIABEL DI KELAS X SMA NEGERI 1 PAMONA BARAT
}

\author{
Hans Pakinde \\ Program Studi Pendidikan Matematika, Fakultas Keguruan dan Ilmu Pendidikan \\ Universitas Kristen Tentena \\ hanspakinde@gmail.com
}

\begin{abstract}
ABSTRAK
Penelitian ini bertujuan untuk mendeskripsikan tingkat pemahaman siswa pada materi sistem persamaan linear tiga variabel di kelas X SMA Negeri 1 Pamona Barat. Metode penelitian ini menggunakan metode penelitian kuantitatif dengan analisis statistik deskriptif untuk mendekripsikan tingkat pemahaman siswa pada materi sistem persamaan linear tiga variabel di kelas X SMA Negeri 1 Pamona Barat dalam menyelesaikan soal-soal sistem persamaan linear tiga variabel. Penelitian dilaksanakan di SMA Negeri 1 Pamona Barat selama tiga (3) bulan. Populasi pada penelitian yaitu keseluruhan jumlah siswa kelas X SMA Negeri 1 Pamona Barat yaitu 100 orang dan jumlah sampel 50 orang. Pengambilan sampel dilaksanakan dengan teknik propotional random sampling. Instrumen yang digunakan dalam penelitian ini adalah tes uraian. Data yang diperoleh kemudian dianalisis dengan statistik deskriptif t-tes satu sampel.

Berdasarkan hasil penelitian menunjukkan bahwa nilai rata $(\bar{x}) 45,24$, Simpangan Baku (Standard Deviation) 10,255, Skor Minimum 15, skor maksimum 62, variansi 105,166 dan jumlah skor keseluruhan 2262 . Nilai $t_{\text {hitung }}=-13,665 \leq t_{\text {tabel }} 1,677$, sehingga $\mathrm{H}_{0}$ diterima dan $\mathrm{H}_{\mathrm{a}}$ ditolak. Maka dapat ditarik kesimpulan dari hasil penelitian bahwa tingkat pemahaman siswa pada materi sistem persamaan linear tiga variabel paling tinggi $65 \%$ dari yang diharapkan sehingga dikategorikan rendah.
\end{abstract}

Kata Kunci : Pemahaman, Sistem Persamaan Linear Tiga Variabel

\section{PENDAHULUAN}

Pendidikan merupakan modal dasar bagi peningkatan kualitas sumber daya manusia, sehingga manusia dituntut untuk terus berupaya mempelajari, memahami dan menguasai berbagai macam disiplin ilmu untuk kemudian diaplikasikan dalam segala aspek kehidupan. Melalui pendidikan, manusia dapat mengembangkan potensi dirinya. Hal itu terkait dengan tujuan pendidikan yang menitikberatkan pada pembentukan dan pengembangan kepribadian. Pembentukan dan pengembangan kepribadian tersebut dapat dicapai melalui latihan dan pengajaran-pengajaran yang terencana dan terarah, artinya kegiatan mengajar yang dilaksanakan, terikat dan terarah pada tujuan pendidikan yang dicapai.

Untuk mencapai tujuan pendidikan tidaklah mudah bagi seorang guru untuk memberikan pemahaman yang benar-benar bisa tertanam kepada siswa. Pemahaman merupakan salah satu tujuan penting dalam pembelajaran untuk memberikan pengertian bahwa materi-materi yang diajarkan kepada siswa bukan hanya sebagai hafalan, namun lebih dari itu, dengan pemahaman, siswa harus lebih mengerti akan konsep matematika karena matematika merupakan ilmu yang penting dalam kehidupan sehari-hari dan matematika sangat diperlukan.

Matematika diperlukan para siswa untuk memenuhi kebutuhan praktis dan untuk memecahkan masalah dalam kehidupan sehari-hari, misalnya dapat menghitung, mengaplikasikan konsep, dan lain sebagainya. Selain itu, matematika juga digunakan untuk membantu dalam pelajaran lain seperti fisika, kimia, dan lain-lain. 
Matematika merupakan ide-ide abstrak yang diberi simbol-simbol konsep dalam matematika harus dipahami sebelum memanipulasi simbol-simbol matematika. Siswa akan lebih mudah memahami konsep matematika apabila siswa tersebut belajar dari yang telah diketahui sebelumnya, sehingga dalam belajar matematika akan lebih mudah jika dilakukan secara kontinu. Sehingga dalam belajar matematika diperlukan suatu proses yang berkesinambungan untuk mencapai kelancaran belajar matematika dan untuk mencapai tujuan belajar. Apabila tujuan pembelajaran matematika telah tercapai, maka proses pembelajaran tersebut dapat dikatakan berhasil.

Keberhasilan pembelajaran matematika dapat diukur atau diketahui oleh guru dengan cara memberikan soal-soal yang berkaitan dengan materi yang diajarkan melalui evaluasi. Evaluasi ini dapat diberikan ketika materi pembelajaran telah selesai. Hasil dari evaluasi inilah yang nantinya dijadikan sebagai pertimbangan oleh guru atau peneliti untuk melihat seberapa besar tingkat pemahaman siswa dalam menguasai materi matematika secara khusus kemampuan dalam menyelesaikan soal yang berkaitan dengan sistem persamaan linear tiga variabel.

Berdasarkan hasil wawancara yang diperoleh dari guru bidang studi matematika di SMA Negeri 1 Pamona Barat, diperoleh informasi dari 100 siswa yang memperoleh hasil belajar di atas Ketuntasan Belajar Minimal (KBM) yaitu 24\% atau sekitar 24 siswa yang memenuhi Ketuntasan Belajar Minimal dimana nilai KBM untuk mata pelajaran matematika adalah 75 . Hal ini menunjukkan bahwa masih banyak siswa kelas X SMA Negeri 1 Pamona Barat yang mendapatkan hasil belajar yang rendah. Ujian akhir semester genap tahun ajaran 2017/2018 ini menggambarkan bahwa pada saat pembelajaran berlangsung sebagian siswa tidak memperhatikan atau tidak memahami materi yang diajarkan.

Pemahaman yang rendah terhadap materi sistem persamaan linear tiga variabel ini membuat siswa sering mengalami kesulitan dalam menyelesaikan soal-soal latihan ketika materi selesai diberikan. Kenyataan ini disebabkan masih ada beberapa siswa yang belum paham tentang sistem persamaan linear tiga variabel. Hal ini juga diperkuat lagi dengan kemampuan siswa belum bisa membuat sistem persamaan linear tiga variabel dari permasalahan kontekstual yang diberikan serta menggunakan metodemetode dalam menyelesaikan soal sistem persamaan linear tiga variabel seperti metode eliminasi, metode substitusi dan metode gabungan (eliminasi-substitusi). Adanya kesulitan-kesulitan yang dialami siswa dalam menyelesaikan soal-soal yang berhubungan dengan materi sistem persamaan linear tiga variabel, maka yang sangat diperlukan yaitu adanya pemahaman konsep dengan baik dan lebih banyak memberikan latihan-latihan soal mengenai materi sistem persamaan linear tiga variabel.

\section{KAJIAN TEORI}

Menurut Sudaryono (2012), pemahaman adalah "kemampuan seseorang untuk mengerti dan memahami sesuatu setelah sesuatu itu diketahui atau diingat, yang mencakup kemampuan untuk menangkap makna dari arti dan bahan yang telah dipelajari, yang dinyatakan dengan menguraikan isi pokok dari suatu bacaan, atau mengubah data yang disajikan dalam bentuk tertentu ke bentuk yang lain".

Menurut Sudijono (1996), pemahaman adalah "kemampuan seseorang untuk mengerti atau memahami sesuatu setelah sesuatu itu diketahui dan diingat". Dengan kata lain, memahami adalah mengetahui tentang sesuatu dan dapat melihatnya dari berbagai segi. Pemahaman merupakan jenjang kemampuan berpikir yang setingkat lebih tinggi dari ingatan dan hafalan. Sementara Purwanto (2013), menyatakan bahwa pemahaman adalah "tingkat kemampuan seseorang yang diharapkan mampu memahami arti atau konsep, situasi, serta fakta yang diketahuinya sehingga seseorang tidak hanya hafal secara verbalistis tetapi juga memahami konsep dari masalah atau fakta yang ditanyakan". Dengan kata lain, memahami adalah mengerti tentang sesuatu dan dapat melihatnya dari berbagai segi. 
Pemahaman merupakan salah satu patokan kompetensi yang dapat dicapai setelah siswa melakukan kegiatan belajar. Dalam proses pembelajaran, setiap siswa memiliki kemampuan yang berbeda-beda dalam memahami apa yang sedang atau sudah siswa pelajari. Ada yang mampu memahami materi secara menyeluruh dan ada pula yang sama sekali tidak dapat mengambil makna dari apa yang telah dipelajari, sehingga yang dicapai hanya sebatas mengetahui. Untuk itu terdapat tingkatantingkatan dalam memahami. berikut:

Sudjana (2010), membagi pemahaman ke dalam tiga kategori, yakni sebagai

a) Tingkat pertama atau tingkat terendah, yaitu pemahaman terjemahan, mulai dari terjemahan dalam arti sebenarnya.

b) Tingkat kedua adalah pemahaman penafsiran, yakni menghubungkan bagian-bagian terdahulu dengan yang diketahui berikutnya, atau menghubungkan beberapa bagian dari grafik dengan kejadian, membedakan yang pokok dan yang bukan pokok

c) Pemahaman tingkat ketiga atau tingkat tertinggi, yakni pemahaman ekstrapolasi. Dengan ekstrapolasi diharapkan mampu melihat di balik yang tertulis, dapat membuat ramalan tentang konsekuensi atau dapat memperluas persepsi dalam arti waktu, dimensi, kasus, ataupun masalahnya.

\section{METODOLOGI PENELITIAN}

Metode yang digunakan adalah metode penelitian kuantitatif dengan analisis statistik deskriptif dengan lokasi penelitian di SMA Negeri 1 Pamona Barat Populasi penelitian terdiri dari seluruh siswa kelas X SMA Negeri 1 Pamona Barat dengan jumlah 100 siswa pada tahun pelajaran 2018/2019. Sampel penelitian ini berjumlah 50 siswa dimana kelas $X$ yang diambil secara acak dari empat kelas yang ada dimana kelas X Mia 1 sebanyak 14 siswa, kelas X Mia 2 sebanyak 14 siswa, kelas X Iis 1 sebanyak 11 siswa, kelas X Iis 2 sebanyak 11 siswa. Data penelitian diperoleh dari hasil tes pemahaman dengan cara menyelesaikan soal yang diberikan sebanyak 5 nomordan instrumen yang digunakan adalah essay tes atau bentuk uraian. Teknik analisis data dalam penelitian ini dilakukan beberapa tahap yaitu sebagai berikut:

1. Tahap Deskripsi data penelitian

Pada tahap deskripsi data hasil penelitian, data-data yang diperoleh dari tes uraian yang diteliti dianalisis dengan statistik deskriptif yaitu dengan nilai rata-rata, skor maksimum, skor minimum, variansi, simpangan baku dan jumlah skor keseluruhan. Dengan tujuan untuk mendeskripsikan karakteristik skor responden dan kemampuan dalam menyelesaikan soal.

Adapun langkah-langkah dalam deskripsi data hasil penelitian deskriptif sesuai dengan yang dilakukan tersebut sebagai berikut:

a. Menghitung skor ideal untuk variabel yang diuji. Skor ideal adalah skor tertinggi karena diasumsikan setiap responden memberi jawaban dengan skor tertinggi.

b. Menghitung rata-rata nilai variabel (Menghitung $\bar{X}$ )

c. Menghitung nilai yang dihipotesiskan (menentukan nilai $\mu_{0}$ )

d. Menghitung nilai simpangan baku (menghitung $S$ )

e. Menghitung jumlah anggota sampel

f. Memasukan nilai-nilai tersebut dalam rumus

2. Tahap Penguji Hipotesis Penelitian

Pada tahap pengujian hipotesis penelitian dilakukan menggunakan analisis statistik deskriptif uji-t satu sampel, yang dirumuskan sebagai berikut:

$t=\frac{\bar{X}-\mu_{0}}{\frac{s}{\sqrt{n}}}$ 
(Sugiyono, 2007)

Keterangan :

$t=$ Nilai t yang dihitung

$\bar{X}=$ Nilai rata-rata

$\mu_{0}=$ Nilai yang dihipotesiskan

$s=$ Simpangan baku sampel

$n=$ Jumlah anggota

Selanjutnya, kriteria pengujian hipotesis dapat dilakukan dengan membandingkan $t_{\text {hitung }}$ dengan $t_{\text {tabel }}$ dengan derajat kebebasan $(\mathrm{dk})=\mathrm{n}-1$ (uji satu pihak) dan taraf kesalahan $\mathrm{a}=5 \%$, dengan syarat jika $\mathrm{t}_{\text {hitung }} \leq \mathrm{t}_{\text {tabel }}$ maka terima $\mathrm{H}_{0}$ dan tolak $\mathrm{H}_{\mathrm{a}}$ dan jika $\mathrm{t}_{\text {hitung }}>\mathrm{t}_{\text {tabel }}$ maka terima $\mathrm{H}_{\mathrm{a}}$ dan tolak $\mathrm{H}_{0}$. Kemudian, untuk melihat seberapa besar tingkat pemahaman siswa dalam menyelesaikan soal-soal yang diberikan, maka digunakan kriteria yang dihitung berdasarkan skor maksimum yang mungkin dicapai siswa dengan pengategorian berdasarkan skor standar, maka rumus yang digunakan adalah sebagai berikut:

$N R=\frac{\text { Skor yang diperole }}{\text { Skor Ideal }} \times 100 \%$

Keterangan

$\mathrm{NR}=$ Presentase nilai rata-rata hasil observasi

(Muslich, 2009)

Pengategorian berdasarkan pada standar umum yang digunakan oleh Suherman (2004) sebagai berikut:

a. Tingkat Pemahaman $90 \%-100 \%$, sangat tinggi

b. Tingkat Pemahaman $75 \%-89 \%$, tinggi

c. Tingkat Pemahaman $55 \%-74 \%$, sedang

d. Tingkat Pemahaman $40 \%-54 \%$, rendah

e. Tingkat Pemahaman $0 \%-39 \%$, sangat rendah

Menganalisis data hasil penelitian, maka digunakan bantuan program Microsoft Office Excel 2007 dan sebagai pembanding bantuan program SPSS 19 (Statistical Product and Service Solution)

\section{HASIL PENELITIAN}

1. Deskripsi Data Hasil Penelitian

Tingkat pemahaman siswa pada materi sistem persamaan linear tiga variabel yang diukur menggunakan bentuk tes esai pada kelas X SMA Negeri 1 Pamona Barat sebanyak 50 siswa. Tes yang diberikan sebanyak 5 soal dan masing-masing butir diberi skor, dimana data yang diambil dalam menyelesaikan sistem persamaan linear tiga variabel dengan metode eliminasi sebanyak 2 butir soal yaitu pada soal nomor 1 dan 2, 1 butir soal dengan metode substitusi pada nomor 3, 2 butir soal pada metode gabungan yaitu nomor 4 dan 5 . Setelah data terkumpul dan diberi nilai atau skor dari pemberian tes tingkat pemahaman siswa pada materi sistem persamaan linear tiga variabel di kelas X SMA Negeri 1 Pamona Barat dianalisis secara deskriptif.

Nilai yang merupakan hasil belajar bagi siswa dianalisis menggunakan statistik deskriptif dengan menggunakan bantuan Program Microsoft Office Excel 2007. Adapun hasil analisis statistik deskriptif terhadap tingkat pemahaman siswa pada materi sistem persamaan linear tiga variabel dapat dilihat pada tabel berikut:

Tabel 4.1 Data Hasil Statistik Deskriptif

\begin{tabular}{|l|l|}
\hline \multicolumn{2}{|l|}{ Data Skor Perolehan } \\
\hline Mean & 45,24 \\
\hline Standard Error & 1,45 \\
\hline Median & 46 \\
\hline
\end{tabular}




\begin{tabular}{|l|l|} 
Mode & 50 \\
\hline Standard Deviation & 10,255 \\
\hline Sample Variance & 105,166 \\
\hline Range & 47 \\
\hline Minimum & 15 \\
\hline Maximum & 62 \\
\hline Sum & 2262 \\
\hline
\end{tabular}

Berdasarkan tabel 4.1 terlihat bahwa nilai rata $(\bar{x})$ 45,24, Simpangan Baku (Standard Deviation) 10,255, Skor Minimum 15, skor maksimum 62, variansi 105,166 dan jumlah skor keseluruhan (sum) 2262.

Jika hasil belajar siswa dikelompokkan dalam kategori sangat rendah, rendah, sedang, tinggi, sangat tinggi akan diperoleh persentase untuk hasil setelah pemberian tes tingkat pemahaman dan berikut tabel distribusi persentase tingkat pemahaman siswa pada materi sistem persamaan linear tiga variabel yang diukur dengan tes esai pada kelas X SMA Negeri 1 Pamona Barat dari 50 siswa dapat dilihat pada tabel berikut:

Tabel 4.2 Distribusi Persentase Tingkat Pemahaman Siswa

\begin{tabular}{|l|l|l|l|}
\hline \multirow{2}{*}{ Interval } & \multicolumn{2}{|l|}{ Hasil Tingkat Pemahaman } & \multirow{2}{*}{ Kategori } \\
\cline { 2 - 4 } & Frekuensi & Persentase (\%) & \\
\hline $90-100$ & - & - & Sangat Tinggi \\
\hline $75-89$ & - & - & Tinggi \\
\hline $55-74$ & 11 & $22 \%$ & Sedang \\
\hline $40-55$ & 28 & $56 \%$ & Rendah \\
\hline $0-39$ & 11 & $22 \%$ & Sangat Rendah \\
\hline
\end{tabular}

Sesuai dengan tabel 4.2 diketahui bahwa dari 50 siswa dikategorikan memiliki kategori sedang adalah 11 siswa (22\%), dikategorikan memiliki kategori rendah 28 siswa $(56 \%)$, dikategorikan memiliki kategori sangat rendah 11 siswa (22\%) dan tidak ada siswa masuk dalam kategori tinggi maupun sangat tinggi.

Dari tabel perhitungan deskriptif persentase di atas menujukan bahwa tingkat pemahaman siswa pada materi sistem persamaan linear tiga variabel yang diukur dengan tes esai pada kelas X SMA Negeri 1 Pamona Barat tahun ajaran 2018/2019 sebesar 56\% sehingga masuk dalam kategori rendah.

Adapun tingkat pemahaman siswa pada materi sistem persamaan linear tiga variabel di kelas X SMA Negeri 1 Pamona Barat per indikator dapat diurai sebagai berikut: a. Menyelesaikan Sistem Persamaan Linear Tiga Variabel dengan metode eliminasi

Hasil deskripsi indikator menyelesaikan sistem persamaan linear tiga variabel dengan metode eliminasi pada soal esai nomor 1 dan 2 ditujukkan pada tabel berikut: Tabel 4.3. Distribusi Frekuensi indikator menyelesaikan sistem

persamaan linear tiga variabel dengan metode eliminasi

\begin{tabular}{|l|l|l|l|}
\hline \multirow{2}{*}{ Interval } & \multicolumn{2}{|l|}{ Hasil Tingkat Pemahaman } & \multirow{2}{*}{ Kategori } \\
\cline { 2 - 4 } & Frekuensi & Persentase (\%) & Sangat Tinggi \\
\hline $90-100$ & - & - & Tinggi \\
\hline $75-89$ & 1 & $2 \%$ & Sedang \\
\hline $55-74$ & 8 & $16 \%$ & Rendah \\
\hline $40-55$ & 21 & $42 \%$ & Sangat Rendah \\
\hline $0-39$ & 20 & $40 \%$ & \\
\hline
\end{tabular}


Berdasarkan tabel di atas dapat diketahui dari 50 siswa diperoleh keterangan tentang indikator menyelesaikan sistem persamaan linear tiga variabel dengan metode eliminasi yaitu sebanyak 1 siswa (2\%) dikategorikan tinggi, 8 siswa (16\%) dikategorikan sedang, 21 siswa (42\%) dikategorikan rendah dan sebanyak 20 siswa (40\%) dikategorikan sangat rendah.

\section{b. Menyelesaikan Sistem Persamaan Linear Tiga Variabel dengan metode Substitusi}

Hasil deskripsi indikator menyelesaikan sistem persamaan linear tiga variabel dengan metode substitusi pada soal esai nomor 3 ditunjukkan pada tabel berikut:

Tabel 4.4. Distribusi Frekuensi indikator menyelesaikan sistem persamaan linear tiga variabel dengan metode substitusi

\begin{tabular}{|l|l|l|l|}
\hline \multirow{2}{*}{ Interval } & \multicolumn{2}{|l|}{ Hasil Tingkat Pemahaman } & \multirow{2}{*}{ Kategori } \\
\cline { 2 - 4 } & Frekuensi & Persentase (\%) & Sangat Tinggi \\
\hline $90-100$ & - & - & Tinggi \\
\hline $75-89$ & - & - & Sedang \\
\hline $55-74$ & 1 & $2 \%$ & Rendah \\
\hline $40-55$ & 11 & $22 \%$ & Sangat Rendah \\
\hline $0-39$ & 38 & $76 \%$ & \\
\hline
\end{tabular}

Berdasarkan tabel di atas dapat diketahui dari 50 siswa diperoleh keterangan tentang indikator menyelesaikan sistem persamaan linear tiga variabel dengan metode substitusi yaitu sebanyak 1 siswa (2\%) dikategorikan sedang, 11 siswa (22\%) dikategorikan rendah dan 38 siswa (76\%) dikategorikan sangat rendah.

c. Menyelesaikan Sistem Persamaan Linear Tiga Variabel dengan metode gabungan

Hasil deskripsi indikator menyelesaikan sistem persamaan linear tiga variabel dengan metode gabungan pada soal esai nomor 4 dan 5 ditunjukkan pada tabel berikut:

Tabel 4.5. Distribusi Frekuensi indikator menyelesaikan sistem

persamaan linear tiga variabel dengan metode gabungan

\begin{tabular}{|l|l|l|l|}
\hline \multirow{2}{*}{ Interval } & \multicolumn{2}{|l|}{ Hasil Tingkat Pemahaman } & \multirow{2}{*}{ Kategori } \\
\cline { 2 - 4 } & Frekuensi & Persentase (\%) & Sangat Tinggi \\
\hline $90-100$ & 2 & $4 \%$ & Tinggi \\
\hline $75-89$ & 12 & $24 \%$ & Sedang \\
\hline $55-74$ & 16 & $32 \%$ & Rendah \\
\hline $40-55$ & 14 & $28 \%$ & Sangat Rendah \\
\hline $0-39$ & 6 & $12 \%$ & \\
\hline
\end{tabular}

Berdasarkan tabel di atas dapat diketahui dari 50 siswa diperoleh keterangan tentang indikator menyelesaikan sistem persamaan linear tiga variabel dengan metode gabungan yaitu sebanyak 2 siswa (4\%) dikategorikan sangat tinggi, 12 siswa (24\%) dikategorikan tinggi, 16 siswa (32\%) dikategorikan sedang, 14 siswa (28\%) dikategorikan rendah dan 6 siswa (12\%) dikategorikan sangat rendah.

\section{Pengujian Hipotesis Penelitian}

Pengujian hipotesis dapat dilakukan dengan membandingkan $t_{\text {hitung }}$ dan $t_{\text {tabel }}$ dengan derajat kebebasan $(\mathrm{dk})=\mathrm{n}-1$ (uji satu pihak) dan taraf kesalahan $\mathrm{a}=5 \%$. Kesimpulan dapat diputuskan dengan ketetapan jika $t_{\text {hitung }}$ lebih kecil dari $t_{\text {tabel }}$ maka $\mathrm{H}_{0}$ diterima dan $\mathrm{H}_{\mathrm{a}}$ ditolak atau sebaliknya.

Untuk variabel tingkat pemahaman siswa pada materi sistem persamaan linear tiga variabel di kelas $X$ SMA Negeri 1 Pamona Barat, nilai yang dihipotesiskan adalah "paling tinggi $65 \%$ dari nilai yang diharapkan". Hal ini berarti $0.65 \times 100=65$, dengan demikian hipotesis dapat dirumuskan sebagai berikut: 
a. $\mathrm{H}_{0}$ dan $\mathrm{H}_{\mathrm{a}}$ dalam bentuk kalimat

$\mathrm{H}_{0}$ : Tingkat pemahaman siswa pada materi sistem persamaan linear tiga variabel paling tinggi $65 \%$ dari yang diharapkan.

$\mathrm{H}_{\mathrm{a}}$ : Tingkat pemahaman siswa pada materi sistem persamaan linear tiga variabel lebih dari $65 \%$ dari yang diharapkan

b. Hipotesis statistik

$H_{0}: \quad \mu \leq 65 \%$

$H_{a}: \quad \mu>65 \%$

Berdasarkan pengujian hipotesis penelitian maka diperoleh nilai $t_{\text {hitung }}$ dengan menggunakan analisis statistik deskriptif uji-t satu sampel sebagai berikut:

$$
\begin{aligned}
t & =\frac{\bar{X}-\mu_{0}}{\frac{s}{\sqrt{n}}} \\
& =\frac{45,240-65}{\frac{10,225}{\sqrt{50}}} \\
& =\frac{-19,76}{\frac{10,225}{7,071}} \\
& =\frac{-19,76}{1,446} \\
& =-13,665
\end{aligned}
$$

Harga $t_{\text {hitung }}$ tersebut dibandingkan dengan harga $t_{\text {tabel }}$ dengan derajat kebebasan $\mathrm{dk}=\mathrm{n}-1=50-1=49$ dan taraf kesalahan $\mathrm{a}=5 \%$ untuk uji satu pihak. Berdasarkan $\mathrm{dk}=49$ dan $\mathrm{a}=5 \%$, ternyata harga $t_{\text {tabel }}$ untuk uji satu pihak 1,677 . Karena harga $t_{\text {hitung }}$ lebih kecil dari harga $t_{\text {tabel }}$ atau jatuh pada daerah penerimaan $\mathrm{H}_{0}(-13,665<$ 1,677) maka $\mathrm{H}_{0}$ diterima dan $\mathrm{H}_{\mathrm{a}}$ ditolak.

\section{PEMBAHASAN}

Sebagaimana yang diungkapkan sebelumnya bahwa, penelitian ini bertujuan untuk mendeskripsikan tingkat pemahaman siswa pada materi sistem persamaan linear tiga variabel di kelas X SMA Negeri 1 Pamona Barat tergolong rendah. Dengan jumlah skor keseluruhan 2262, skor rata-rata $(\bar{x})$ 45,240, Skor Minimum 15, skor maksimum 62, variansi 105,166 dan simpangan baku (Standard Deviation) 10,255. Berdasarkan hasil perhitungan nilai $t_{\text {hitung }}$ didapatkan $-13,665$. Dengan demikian $\mathrm{H}_{0}$ diterima dan $\mathrm{H}_{\mathrm{a}}$ ditolak, karena harga harga $t_{\text {hitung }}$ kurang dari pada $t_{\text {tabel }}(-13,665 \leq 1,677)$.

Dari hasil analisis per indikator yang dilihat dari nilai rata-rata dan persentase tertinggi dalam menyelesaikan sistem persamaan linear tiga variabel dengan metode eliminasi yaitu sebanyak 21 siswa (42\%) dikategorikan rendah dengan nilai rata-rata 43,8 . Maka terlihat dalam menyelesaikan sistem persamaan linear tiga variabel dengan metode eliminasi tergolong rendah. Pada indikator menyelesaikan sistem persamaan linear tiga variabel dengan metode substitusi yaitu sebanyak 38 siswa (76\%) dikategorikan sangat rendah dengan nilai rata-rata 23,1. Maka terlihat dalam menyelesaikan sistem persamaan linear tiga variabel dengan metode eliminasi tergolong sangat rendah. Pada indikator menyelesaikan sistem persamaan linear tiga variabel dengan metode gabungan yaitu sebanyak 16 siswa (32\%) dikategorikan sedang dengan nilai rata-rata 57,75 . Maka terlihat dalam menyelesaikan sistem persamaan linear tiga variabel dengan metode gabungan tergolong sedang.

Hasil analisis keseluruhan dalam penelitian ini bahwa tingkat pemahaman siswa pada materi sistem persamaan linear tiga variabel di kelas X SMA Negeri 1 Pamona Barat paling tinggi $65 \%$ dari yang diharapkan. Sesuai dengan skor yang diperoleh, diketahui 
bahwa dari 50 siswa dikategorikan memiliki kategori sedang adalah 11 siswa (22\%), dikategorikan memiliki kategori rendah 28 siswa (56\%), dikategorikan memiliki kategori sangat rendah 11 siswa (22\%) dan tidak ada siswa masuk dalam kategori tinggi maupun sangat tinggi. Maka jelas terlihat bahwa tingkat pemahaman siswa pada materi sistem persamaan linear di kelas X SMA Negeri 1 Pamona Barat dikategorikan rendah.

\section{KESIMPULAN}

Berdasarkan hasil penelitian dan pembahasan sebelumnya, maka diperoleh hasil tes tingkat pemahaman siswa pada materi sistem persamaan linear tiga variabel di kelas $\mathrm{X}$ SMA Negeri 1 Pamona Barat dari 50 siswa dikategorikan memiliki kategori sedang adalah 11 siswa (22\%), dikategorikan memiliki kategori rendah 28 siswa (56\%) dan dikategorikan memiliki kategori sangat rendah 11 siswa (22\%). Jadi dapat disimpulkan bahwa tingkat pemahaman siswa pada materi sistem persamaan linear tiga variabel di kelas X SMA Negeri 1 Pamona Barat dikategorikan rendah dengan nilai rata-rata 45,24 sehingga hipotesis yang menyatakan tingkat pemahaman siswa pada materi sistem persamaan linear tiga variabel paling tinggi $65 \%$ dari yang diharapkan dapat di terima, karena $\mathrm{H}_{0}$ diterima dan $\mathrm{H}_{\mathrm{a}}$ ditolak dimana harga $\mathrm{t}_{\text {hitung }}$ kurang dari pada $\mathrm{t}_{\text {tabel }}(-13,665 \leq$ $1,677)$.

Adapun kendala yang dihadapi siswa dalam menyelesaikan soal-soal sistem persamaan linear tiga variabel adalah rendahnya kemampuan siswa mengubah kalimat matematika kedalam bentuk operasi atau simbol matematika pada sistem persamaan linear tiga variabel.

\section{SARAN}

Sesuai dengan hasil diperoleh dari hasil penelitian ini, maka diajukan saran-saran sebagai berikut:

1. Guru: hendaknya mengingatkan kembali bagaimana cara mengubah kalimat matematika kedalam bentuk operasi atau simbol matematika sebelum mempelajari materi sistem persamaan linear tiga variabel.

2. Peneliti : hendaknya dapat dijadikan sebagai acuan dalam penelitian selanjutnya agar mampu memberikan kontribusi bagi upaya peningkatan mutu dan kualitas pendidikan dan penelitian ini diharapkan bisa digunakan sebagai referensi dan penambah pengetahuan untuk peneliti selanjutnya.

\section{DAFTAR PUSTAKA}

Muslich, Mansur. 2009. Melaksanakan penelitian tindakan kelas. Bandung:PT. Remaja Rosdakarya

Purwanto, Ngalim. 2013. Prinsip-prinsip dan Teknik Evaluasi Pengajaran. Bandung: Remaja Rosdakarya.

Sudaryono. 2012. Dasar-dasar Evaluasi Pembelajaran. Yogyakarta: Graha Ilmu.

Sudijono, Anas. 1996. Pengantar Evaluasi Pendidikan. Jakarta: Raja Grafindo Persada.

Sudjana. 2010. Evaluasi Proses dan Hasil Pembelajaran. Jakarta: Bumi Aksara.

Suherman. 2004. Evaluasi Proses dan Hasil Belajar Matematika. Depdikbud. Jakarta.

Sugiyono. 2007. Metode Penelitian Kuantitatif, Kualitatif dan R\&D. Bandung: Alfabeta 